\title{
FROD DALAM URUS NIAGA TANAH: SATU KAJIAN PERBANDINGAN DENGAN UNDANG-UNDANG TANAH AUSTRALIA ${ }^{1}$
}

\author{
Noraida binti Harun \\ Universiti Sultan Zainal Abidin (UniSZA) ${ }^{2}$
}

\begin{abstract}
Abstrak
Falsafah sistem Torrens ialah ia merupakan satu sistem pentadbiran tanah berasaskan pendaftaran. Sebagai asas sistem Torrens, pendaftaran adalah prasyarat hak milik yang tidak boleh disangkal. Kesan daripada pendaftaran ialah undang-undang mengurniakan kepada penerima pindah milik, pemajak atau pemegang gadaian atau penerima isemen, hak milik yang tidak boleh disangkal. Tetapi sejak mutakhir ini banyak kejadian jenayah kes frod dalam urus niaga tanah menunjukkan peningkatan dari masa ke semasa. Peningkatan kes-kes ini menimbulkan rasa bimbang oleh pemilik-pemilik tanah di atas keselamatan harta mereka kerana tanah mereka boleh bertukar milik tanpa disedari. Sehubungan dengan itu, artikel ini dibuat bagi membincangkan kes frod yang berlaku dalam konteks urus niaga tanah di Malaysia dan membuat perbandingan dengan undang-undang tanah Australia serta mengenal pasti apakah jenisjenis frod yang berlaku dan seterusnya mencadangkan jalan penyelesaian yang difikirkan sesuai bagi menjamin kepentingan dan hak-hak semua pihak yang terlibat.
\end{abstract}

Katakunci: frod, urus niaga tanah, jenis-jenis frod, cadangan dan penyelesaian, kajian Perbandingan

\section{Pendahuluan}

Falsafah sistem Torrens ialah ia merupakan satu sistem pentadbiran tanah berasaskan pendaftaran. Sebagai asas sistem Torrens,

1 Kertas kerja yang dibentangkan di The $6^{\text {th }}$ UUM International Legal Conference 2011: 'Facing The Contemporary Global Legal Challenges' pada 19-20 November di Bayview Beach Resort, Penang.

2 Pensyarah, Fakulti Undang-undang dan Hubungan Antarabangsa, Universiti Sultan Zainal Abidin (UniSZA), Kampus Gong Badak,21300 Kuala Terengganu, Terengganu, sedang menyambung pelajaran di peringkat PHD di Universiti Kebangsaan Malaysia.Tel. No: 09-6653310, E-mail: noraida@unisza.edu.my 
pendaftaran adalah prasyarat hak milik yang tidak boleh disangkal. Menurut Hakim Suriyadi dalam kes Sime Bank v Mohd Hassan bin Sulaiman: ${ }^{3}$

"The National Land Code 1965 was made effective from $1^{\text {st }}$ of January 1966 whereby thenceforth a uniform system of land tenure and dealing existed throughout Peninsular Malaysia, Penang and Malacca were also absorbed into the system by the promulgation of the National Land Code (Penang and Malacca) Titles Act 1963. In a gist, the system practiced is commonly referred to as the Torrens System or the registration of titles. It owned it's origin or name after Sir Robert Torrens, who earlier had introduced it into South Australia which thereafter spread throughout Australia and eventually reaching our shores"4

Oleh itu, sistem Torrens merupakan suatu sistem pendaftaran hak milik dan urus niaga ke atas tanah bagi menghasilkan suatu sistem yang boleh dipercayai, mudah, murah, cepat dan sesuai dengan keperluan masyarakat amnya. Sistem ini juga merupakan suatu cara pemindahhakkan di mana hak milik tanah dan kepentingannya bergantung pada pendaftaran dan bukannya kepada instrumen di antara pihak yang terlibat. Ia menggambarkan bahawa pendaftaran merupakan suatu langkah yang penting dalam usaha untuk memperolehi hak milik terhadap tanah. ${ }^{5}$ Sistem Torrens juga memperuntukkan jaminan kepada pemilik tanah bahawa hak milik mereka ke atas tanah adalah hak milik mutlak dan jaminan juga diberikan kepada pemilik tanah berdaftar yang mengalami kerugian di mana pampasan akan disediakan kepada pemilik tanah berdaftar yang telah mengalami kerugian. Dengan erti kata lain, sistem Torrens menyediakan pampasan sebagai gantirugi ke atas kehilangan hak atau kepentingan berdaftar kerana pendaftaran berpunca daripada

3 [2000] 2 MLJ 158.

4 Ibid., 61.

5 Ainul Jaria Maidin, "Historical Development of Land Law in Malaysia", dalam Principles Of Malaysian Land Law, ed..Ainul Jariah, Sharifah Zubaidah Syed Abdul Kader, Bashiran Begum, et.al, (Kuala Lumpur: Lexis Nexis, Malayan Law Journal, 2008), 45. 
kesilapan, salah nyata, penipuan dan pemalsuan maklumat dan instrumen. ${ }^{6}$ Sir Robert Torrens ${ }^{7}$ memperkatakan bahawa:

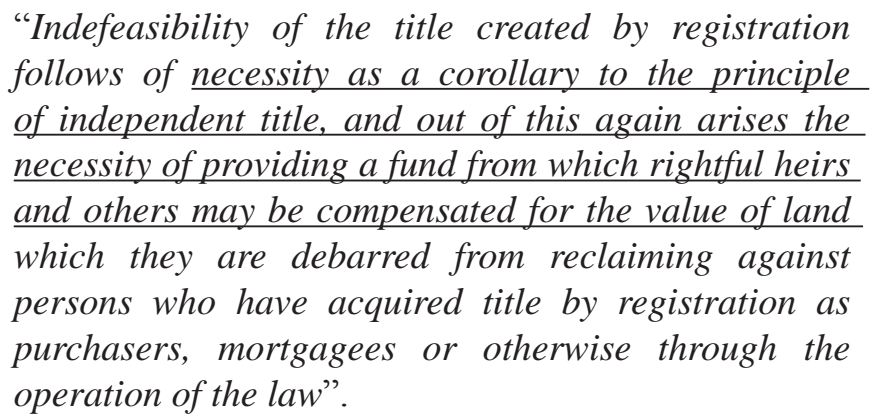

Oleh itu Torrens mengiktiraf bahawa jaminan kerajaan dalam bentuk pampasan diberikan kepada mereka yang kehilangan hak atau kepentingan disebabkan oleh Pendaftar atau mana-mana pegawai yang berkerja di pejabat pendaftaran tanah mungkin akibat ketinggalan, kesilapan (mistake) dan misfeasans. Tetapi jaminan ini tidak menjadi sebahagian daripada sistem Torrens yang diamalkan di Malaysia. ${ }^{8}$

Sejajar dengan prinsip utama sistem Torrens bahawa "daftar adalah segala-galanya", Kanun Tanah Negara 1965 (KTN) mengehendaki semua transaksi di bawahnya menggunakan borang-borang tertentu, diikuti dengan proses pendaftaran dengan Pihak Berkuasa. Kesan daripada pendaftaran ini, undang-undang mengurniakan kepada penerima pindah milik, pemajak atau pemegang gadaian atau

6 Mohd Shukri Ismail, Cadangan Memperkenalkan Dana Asurans Di Bawah Prinsip Insuran Sistem Torrens Sebagai Langkah Perlindungan Kuantitatif Kepada Mangsa Pemalsuan Dan Penipuan Hak Milik Tanah, Mesyuarat Pengarah Tanah Malaysia Bil.1/2008, JKPTG, hlm 4.

7 Robert R Torrens, The South Australian System OfConveyancing By Registration Of Title (Adelaide :Register and Observer General Printing Offices, 1859) hlm 9, lihat juga Mohd Shukri Ismail, Cadangan Memperkenalkan Dana Asurans Di Bawah Prinsip Insuran Sistem Torrens Sebagai Langkah Perlindungan Kuantitatif Kepada Mangsa Pemalsuan Dan Penipuan Hak Milik Tanah, Mesyuarat Pengarah Tanah Malaysia Bil.1/2008, JKPTG, hlm 5.

8 Menurut KS Dass, The Torrens System in Malaya (Singapura :Malayan Law Journal Limited, 1963) 97, beliau berpandangan bahawa dengan ketiadaan prinsip insuran di negeri-negeri Melayu, ia akan menambahkan liabiliti ke atas tuan punya tanah berdaftar dan mungkin boleh menghalang pembangunan negara dan exploitasi sumber-sumber. 
penerima isemen, hak milik yang tidak boleh disangkal. ${ }^{9}$ Dalam kes Frazer Iwn Walker, ${ }^{10}$ Lord Wilberforce merujuk istilah "hak milik yang tidak boleh disangkal" sebagai perlindungan daripada serangan pihak lawan yang membuat tuntutan ke atas tanah atau kepentingan yang telah didaftarkan yang dinikmati oleh pemilik berdaftar. Konsep ini menjadi pokok kepada sistem pendaftaran.

\section{Konsep Frod/ Penipuan di bawah KTN dan Sistem Torrens}

Seksyen 340(2)(a) KTN menetapkan bahawa:

(2) Hak milik atau kepentingan mana-mana orang atau badan sedemikian janganlah hendaknya menjadi tak boleh disangkal:-

(a) dalam mana-mana hal frod... yang orang atau badan itu, atau mana-mana agen atau badan itu, adalah menjadi satu pihak atau bahagiannya;

Seksyen 340(2)(a) KTN memperuntukkan bahawa jika seseorang atau ejennya menjadi pihak atau tahu tentang kewujudan frod, hak milik yang diperoleh oleh orang berkenaan akan boleh disangkal. Ini bermakna seseorang yang telah melakukan frod tidak akan mendapat perlindungan melalui pendaftaran. Walaupun KTN memandang serius tentang kewujudan frod, tetapi KTN tidak menerangkan dengan jelas tentang perlakuan yang bagaimanakah yang dikatakan frod seperti yang dimaksudkan dalam KTN. Oleh itu tafsiran kehakiman tentang definisi frod dalam bidang kuasa Torrens harus diambil kira. ${ }^{11}$

Majlis Privy dalam kes Assets Co Iwn Mere Roihi ${ }^{12}$, telah mentakrifkan frod sebagai:

"By fraud in these (Torrens) Acts is meant actual fraud, ie dishonesty of some sort, not what is called constructive or equitable fraud"13

9 Seksyen 340(1) KTN 1965.

10 [1967] AC 569.

11 Visu Sinnadurai, Jual Beli Harta Tanah Di Malaysia (Kuala Lumpur: Dewan Bahasa dan Pustaka, 1996), 319.

12 [1905] AC 176.

13 Ibid., 210. 
Definisi frod ini juga diterima pakai di Malaysia. ${ }^{14}$ Dalam kes PJTV Denson (M) Sdn Bhd lwn Roxy (M) Sdn Bhd, ${ }^{15}$ Raja Azlan Shah menyatakan bahawa:

"Whether fraud exits is a question of fact, to be decided upon the circumstances of each particular case. Decided cases are only illustrative of fraud. Fraud must mean 'actual fraud' ie dishonesty of some sort' for which the registered proprietor is a party or privy. "Fraud is the same in all courts, but such expressions as 'constructive' are...inaccurate;” but 'fraud... implies a willful act, on the part of one, whereby another is sought to be deprived, by unjustifiable means, of what he is entitled." 16 Thus in Waimiha Sawmiling Co Ltd $v$ Waione Timber Co Ltd, ${ }^{17}$ it was said that" if the designed object of a transfer to be cheat a man of a known existing right, that is fraudulent..."18

Dalam aspek frod, perkara yang penting perlu dibuktikan ialah frod yang dilakukan merupakan frod sebenar. ${ }^{19}$ Menurut Hakim Salmond

14 Contohnya Kes Mohamed Isa lwn Haji Ibrahim [1968] 1 MLJ 186, Mahkamah Persekutuan menyatakan bahawa mengikut seksyen 43(2) Enakmen Tanah Kedah, frod bermakna fraud sebenar seperti yang dinyatakan dalam keputusan Majlis Privy dalam kes Assets Co Ltd lwn Mere Roihi [1905] AC 176

15 [1980] 2 MLJ 136.

16 Per Romilly MR in Green v Nixon (1857) 23 Beav 530 dan 535, 53 ER 208

17 [1926] AC 101.

18 Ibid,. 138. Lihat juga Datuk Jaginder Singh \& Ors v Tara Rajaratnam [1983] 2 MLJ (FC) and [1983] 2 MLJ 127 (HC) and Tai Lee Finance Co Sdn Bhd v Official Assignee \& Ors [1983] 1 MLJ 81 (FC).

19 Dalam bahasa Inggeris, ia dirujuk sebagai 'actual fraud.' This has ben defined as 'dishonesty- a willful and conscious disregard and violation of the rights of other persons' (Waimiha Sawmiling Co Ltd lwn Wajone Timber Co Ltd (1923) NZLR 1137, Salmond J at page 1173), or as, something in the nature of personal dishonesty or moral turpitude' (Stuart $v$ Kingston (1923) 32 CLR 309 , Knox CJ at page 329), or fraud must be brought home to the person whose registered title is impeached or to his agents. Fraud by persons through whom he claims does not affect him unless knowledge of it is brought home to him or his agents (Assets ov Mere Roihi [1905] AC 176, at page 210), lihat juga Judith Sihombing, National Land Code, A Commentary (Kuala Lumpur: Malaysian Law Journal, 1992), 805, lihat juga Joshua Kevin Sathiaseelan, Prinsip-prinsip Penting Perundangan Tanah di Malaysia (Selangor: Lexis Nexis Malayan Law Journal, 2006), 80-81. 
J dalam kes Waimiha Sawmiling Co Ltd lwn Wajone Timber Co Ltd ${ }^{20}$, frod sebenar adalah ketidakjujuran yang disengajakan dan tanpa pengendahan dan melanggar hak pihak yang lain. ${ }^{21}$ Selain itu juga, pemilik baru juga merupakan pihak ataupun privy kepada frod di mana hak milik tersebut diperolehi. ${ }^{22}$ Perkara ini amat penting yang perlu dibuktikan oleh pemilik asal kerana menurut kes Bagher Singh Iwn Chanan Singh $^{23}$ tanpa pembuktian adalah agak sukar untuk membuktikan suatu frod dan juga untuk menyangkal hak milik yang diperolehi melalui frod. ${ }^{24}$ Ini adalah kerana jika pembeli berdaftar mungkin akan mengetahui tentang frod jika dia lebih berhati-hati dan telah membuat penyiasatan yang lebih lanjut, tetapi dia telah gagal melakukannya, tidak dengan sendirinya membuktikan frod di pihak pembeli berdaftar itu. ${ }^{25}$

Syed Agil Barakbah menjelaskan lagi mengenai konsep frod sebenar dalam kes Mahkamah Tinggi Lian Keow Sdn Bhd lwn Overseas Credit Finance (M) Sdn Bhd ${ }^{26}$ seperti berikut:

"Fraud under the Code means actual and not constructive or equitable fraud. Actual fraud must be proved in order to deprive a purchaser for value of the absolute title conferred by the Code. Actual fraud means dishonesty of some sort proved against the person whose registered title is impeached, or his agents. Bona fide mistake or negligence is not fraud and each case must depend on its own particular circumstances. The equitable doctrine of constructive fraud has no application under the provisions of the Code $^{27}$. This is the view adopted by our courts based on

20 [1923] NZLR 1137.

21 'Dishonesty - a willful and conscious disregard and violation of the rights of other persons'. Lihat juga Joshua Kevin Sathiaseelan, Prinsip-prinsip Penting Perundangan Tanah di Malaysia (Selangor: Lexis Nexis Malayan Law Journal, 2006), 80.

22 Ibid.

23 [1961] MLJ 328.

24 Joshua Kevin Sathiaseelan, 80.

25 Per Lord Lindley dalam kes Assets Co lwn Mere Roihi [1905] AC 176,210, Lihat juga Visu Sinnadurai, Jual Beli Harta Tanah Di Malaysia (Kuala Lumpur: Dewan Bahasa dan Pustaka, 1996), 320-321.

26 [1988] 2 MLJ 449.

27 Ibid., 465. 
the decision in Waimiha Sawmilling Co Ltd $v$ Waione Timber Co Ltd, which followed Assets Co Ltd v Mere Roihi". ${ }^{28}$

Dalam kes Goh Hooi Yin Iwn Lim Teong Ghee \& Ors ${ }^{29}$ Hakim Edgar Joseph Jr juga menekankan bahawa dalam frod sebenar, perkara penting yang perlu dibuktikan ialah niat untuk menipu:

"It is not enough to show that the transfer had the effect of depriving the plaintiff of a known existing right. It must be demonstrated that the transfer was executed with the intention of cheating the plaintiff of such right. Furthermore, it is immaterial to decide whether there were other intentions and equally immaterial to decide which was the dominant intention. The intention to cheat must be one which has a substantial influence on the decision to make the transfer" ${ }^{\prime 3}$

Menurut kes di atas, tidak mengambil kira jenis frod yang dilakukan, jika tiada niat untuk menipu maka tiada frod yang berlaku bagi tujuan maksud KTN.

Dalam kes Tai Lee Finance Co Sdn Bhd Iwn Official Assignee \& Ors ${ }^{31}$ sebuah syarikat pemaju perumahan telah menjual beberapa lot tanah dalam projeknya kepada beberapa orang pembeli. Keseluruhan tanah itu kemudian telah digadaikan oleh pemaju kepada sebuah syarikat kewangan (pemegang gadaian) sebagai sekuriti pinjaman yang diperoleh daripada syarikat tersebut. Setelah masa berlalu, pemajau perumahan menghadapi kesulitan membayar balik pinjamannya kepada pemegang gadaian. Keadaaan menjadi bertambah genting apabila pemegang gadaian mengambil tindakan melelong tanah yang digadai untuk mendapatkan balik wang pinjaman. Pada masa itu beberapa orang pembeli lot tanah telah mencelah. Hakim Chan menyatakan bahawa frod hendaklah sesuatu yang benar berlaku (actual fraud) dan bukannya fraud konstruktif. Hakim seterusnya menyatakan bahawa pengetahuan pemegang gadaian bahawa tanah

28 [1923] NZLR 1137, [1905] 1 AC 176.

29 [1990] 3 MLJ 23.

30 Ibid., 34.

31 [1983] 1 MLJ 32. 
yang digadai itu tertakluk kepada kepentingan benefisial beberapa orang pembeli bukan merupakan frod.

Oleh itu boleh dikatakan bahawa frod mestilah bermakna frod yang sebenar, iaitu ketakjujuran iaitu pemilik berdaftar menjadi salah satu daripada pihak yang terlibat dengan frod. Frod juga membayangkan perbuatan yang disengajakan oleh seseorang yang dilakukan dengan cara yang salah, menyebabkan seorang yang lain kehilangan apa yang dia berhak. Oleh itu boleh dirumuskan bahawa beberapa aspek penting perlu dibuktikan bahawa terdapat frod adalah seperti berikut:

1) Penipuan yang dilakukan merupakan frod sebenar (actual fraud);32

2) Pemilik asal membuktikan bahawa pemilik baru yang telah memperoleh hak milik melalui frod adalah pihak ataupun privy kepada frod; ${ }^{33}$

3) Niat untuk menipu ${ }^{34}$;

4) Penipuan tidak boleh berdasarkan frod konstruktif iaitu pengetahuan berkenaan dengan adanya satu kepentingan terdahulu atau frod.

Dalam konsep sistem Torrens itu sendiri, tidak terdapat definisi frod. Perkataan frod yang digunakan dalam undang-undang Torrens yang diguna pakai dalam setiap wilayah di Australia adalah dalam keadaan dua keadaan iaitu:

1) Dalam pengecualian statutori kepada prinsip hak milik yang tidak boleh disangkal, frod disenaraikan sebagai satu pengecualian. Dalam peruntukan-peruntukan ini, frod yang dilakukan oleh pemilik tanah berdaftar akan menyebabkan dia kehilangan hakmilik boleh sangkal pada hak miliknya. ${ }^{35}$

32 Waimiha Sawmiling Co Ltd lwn Waione Timber Co Ltd [1923] NZLR 1137, Hakim Salmond memutuskan bahawa frod sebenar adalah ketidakjujuran yang disengajakan dan tanpa pengendahan dan melanggar hak pihak yang lain.

33 Assets Co lwn Mere Roihi [1905] AC 176 hlm 210, mahkamah memutuskan bahawa: "...must be brought home to the person whose registered title is impeached or to his agents. Fraud by persons through whom he claims does not affect him unless knowledge of it is brought home to him or his agents."

34 Goh Hooi Yin v Lim Teong Ghee \& Ors [1990] 3 MLJ 23.

35 Transfer of Land Act 1958 (Victoria) seksyen 42\&43, Real Property Act 1900 (NSW) seksyen 42(1), Land Title Act 1994 (Qld) seksyen 184, Real Property Act 1886(SA) seksyen 69(b), Land Title Act 2000(NT) seksyen 188, Land Titles Act 1925 (ACT) seksyen 58, Land Titles Act 1980 (Tas) seksyen 40 dan Transfer of Land Act 1893 (WA) seksyen 68. 
2) Dalam peruntukan pampasan ${ }^{36}$ yang menyenaraikan keadaan di mana pihak berkenaan boleh menuntut pampasan disebabkan oleh penarikan balik kepentingan pada tanah yang disebabkan oleh operasi sistem Torrens. Kerugian disebabkan oleh frod merupakan salah satu keadaan yang membolehkan pemilik tanah berhak menuntut pampasan; apabila pemilik tanah berdaftar menanggung kerugian melalui prinsip insurans sistem Torrens, di samping jaminan diberikan kepada hak milik mereka adalah mutlak, maka pampasan akan diberikan kepada kerugian yang telah dialami oleh pemilik tanah berdafar tersebut.

Tetapi dalam kedua-dua keadaan di atas, tiada penerangan tentang definisi dalam perundangan mengenai maksud frod (fraud). Oleh itu terpulanglah kepada interpretasi kehakiman untuk menentukan apa yang terjumlah sebagai frod. Oleh itu terma 'fraud' hanya terhad pemakaiannya kepada frod sebenar. ${ }^{37}$ Ketiadaan definisi frod dalam KTN telah membolehkan mahkamah memutuskan bahawa frod wujud dalam kes-kes tertentu apabila pihak yang berkenaan bertindak secara tidak jujur, menipu atau tindakan-tindakan lain yang bertentangan dengan moral. ${ }^{38}$ Oleh itu persoalan sama ada wujudnya frod atau sebaliknya merupakan persoalan fakta yang akan ditentukan berdasarkan hal keadaan setiap kes yang berkenaan dimana perbuatan dan niat perlu hadir.

36 Transfer of Land Act 1958 (Victoria) seksyen 109-110, Real Property Act 1900 (NSW) seksyen 129, Land Title Act 1994 (Qld) seksyen 173-175, Real Property Act 1886(SA) seksyen 201-219, Land Title Act 2000(NT) seksyen 188, Land Titles Act 1925 (ACT) seksyen 154-159, Land Titles Act 1980 (Tas) seksyen 150-159 dan Transfer of Land Act 1893 (WA) seksyen 201-2, Land Title Act 2000 (NT) seksyen 192-196.

37 Rouhshi Low, "The Use Of Technology To Automate The Registration Process Within The Torrens System And Its Impact On Fraud: An Analysis" ( PhD diss., Queensland University of Technology, 2008), 32. Seperti dinyatakan juga dalam kes Assets Co Ltd v Mere Roihi [1905] AC 176, p 210 : ‘... by fraud in these Acts is meant actual fraud, ie dishonesty of some sort, not what is called constructive or equitable fraud', juga lihat Bahr v Nicolay (No 2) (1988) Bahr v Nicolay (No 2) (1988) 164 CLR 604, p 614: ' actual fraud, personal dishonesty or moral turpitude lie at the heart of the [fraud provisions]' dan Grgic v ANZ Banking Group Ltd (1994) 33 NSWLR 202,221 : 'Fraud comprehends actual fraud, personal dishonesty or moral turpitude on the part of the registered proprietor of the subject estate or interest or of that registered proprietor's agents'.

38 Visu Sinnadurai, Jual Beli Harta Tanah Di Malaysia (Kuala Lumpur : Dewan Bahasa dan Pustaka, 1996), 335. 


\section{Frod dalam Urus Niaga Tanah}

Frod merupakan satu masalah yang serius dalam pelaksanaan sistem pendaftaran hak milik tanah di Malaysia. Sebagai contoh apa yang diperkatakan oleh peguam bela dan peguam cara Anthony Wong Fook Hin dalam 15th Malaysian Law Conference 2010 ${ }^{39}$, kebanyakan kes-kes frod dan pemalsuan yang terlibat adalah kes 'identity fraud' iaitu sama ada identiti pemilik tanah dipalsukan atau memalsukan kad pengenalan dan juga memalsukan tandatangan serta pengakuan. Peningkatan kes-kes ini menimbulkan rasa kebimbangan pemilik-pemilik tanah terhadap keselamatan harta mereka kerana tanah mereka boleh bertukar milik tanpa disedari. Antara faktor penyumbang kepada gejala ini adalah kerana peningkatan nilai hartanah itu sendiri, tanah yang terbiar dan kelemahan-kelemahan pengurusan di pejabat tanah. Kebiasaannya, terdapat dua kesalahan jenayah yang dikesan semasa frod urusan tukar hak milik tanah di pejabat tanah, iaitu pemalsuan suratan yang dikemukakan (forgery) dan juga jenayah frod (cheating) ${ }^{40}$ Pada Julai 2007, Timbalan Menteri Kementerian Keselamatan Dalam Negeri, Datuk Johari Baharum memberitahu Dewan Rakyat bahawa jumlah tanah yang dipindah milik melalui pemalsuan tandatangan penjual telah meningkat semenjak 2001. Pada tahun 2001 hanya ada 16 kes dan ianya telah meningkat kepada 19 kes pada tahun 2002 dan 22 kes pada tahun 2003. Pada tahun 2004 bilangannya telah meningkat kepada 32 kes dan 35 kes pada tahun 2005 dan 40 kes pada tahun $2006 .{ }^{41}$ Mengikut kepada laporan statistik polis yang melibatkan kes frod dan pemalsuan di Malaysia antara tahun 2005 hingga 2009 ialah sebanyak 398 kes. $^{42}$

39 Kevin Kam and Shanmuga Kanesalingam, "MLC 2010: Recent Federal Court's Decision on section 340 of the National Land Code 1965: Tan Ying Hong v Tan Sian San \& Ors - Are Landowners and Banks Secured?” http:// www.malaysianbar.org (akses pada 31 Julai 2010).

40 Suhaimi Othman, "Frod Dalam Urusan Tanah: Isu dan Penyelesaian" Jurnal INSTUN 1, Bil 2 (2008), http://www.instun.gov.my/index2.php?option=com docman\&task=doc_view\&gid=189\&Itemid=99999999 (akses pada 30 Julai 2011).

41 http://www.parlimen.gov.my/hindex/pdf/DR-19112007.pdf.(akses pada 6 Januari 2010)

42 Shaila Koshy, "Your Land Can Land In The Wrong Hands", The Star, August 8, 2010. 


\section{Jenis-jenis Frod}

Antara jenis-jenis frod yang berlaku di Malaysia berdasarkan keskes yang telah diputuskan oleh Mahkamah adalah seperti berikut:

\begin{tabular}{|c|c|}
\hline JENIS-JENIS FROD & CARA FROD \\
\hline Pemalsuan tandatangan $^{1}$ & Penipuan gadaian, pindah milik \\
\hline Pemalsuan pindah milik ${ }^{2}$ & Pemalsuan Dokumen Hak milik \\
\hline Surat Kuasa Wakil (PA) ${ }^{3}$ & Penipuan gadaian \\
\hline Perjanjian jual beli (PJB $\left.{ }^{4}\right)$ & $\begin{array}{l}\text { Penipuan dalam menandatangani dokumen } \\
\text { dokumen melepaskan gadaian }\end{array}$ \\
\hline Penipuan oleh peguam ${ }^{5}$ & Urusan Pindah milik dan jual beli \\
\hline $\begin{array}{l}\text { Penipuan dalam memindah } \\
\text { milik saham-saham dan } \\
\text { harta-harta/aset dalam } \\
\text { syarikat }{ }^{6}\end{array}$ & $\begin{array}{l}\text { Memindah milik kesemua saham dar } \\
\text { mendaftarkan atas nama defendan tanp } \\
\text { kebenaran atau pengetahuan plaintif } \\
\text { tandatangan dipalsukan }\end{array}$ \\
\hline Penipuan jual-janji ${ }^{7}$ & $\begin{array}{l}\text { Pindah milik tanah semasa perjanjian jual } \\
\text { janji masih berkuatkuasa }\end{array}$ \\
\hline
\end{tabular}

Di Malaysia, sistem Pendaftaran Tanah Berkomputer (SPTB $)^{43}$ adalah suatu sistem yang telah dibangunkan pada tahun 1990 oleh Kementerian Sumber Asli dan Alam Sekitar (NRE) yang dahulunya dikenali sebagai Kementerian Tanah dan Pembangunan Koperasi (KTPK) dengan kerjasama Kerajaan Sweden. Projek SPTB telah bermula pada 1989 dan sebagai langkah utama projek perintis telah dimulakan. Pelaksanaan Sistem SPTB telah dibahagikan kepada dua fasa iaitu Fasa 1 dan Fasa 2. Pelaksanaan SPTB Fasa 1 telah bermula pada tahun 1996-1998 dan melibatkan negeri Perlis, Kedah, Terengganu, Pahang dan Kuala Lumpur. Manakala pelaksanaan Fasa 2 telah bermula pada permulaan tahun 2001 dan telah dilaksanakan di negeri Pulau Pinang, Perak, Selangor, Negeri Sembilan, Melaka, Johor dan Kelantan. Objektif penubuhan sistem SPTB ialah untuk memodenkan kaedah pendaftaran hak milik dan urus niaga tanah dan menjadikan prosedur pendaftaran lebih efektif dan tidak mengabaikan aspek keselamatan di samping memudahkan

43 Menurut seksyen 5A, Jadual Keempat Belas, SPTB bermaksud prosedurprosedur untuk pendaftaran hak milik, dokumen-dokumen yang dikehendaki disediakan dengan cara itu dan apa-apa pemasukan dalam mana-mana dokumen hak milik melalui penggunaan sebuah komputer. Sistem ini termasuk keduadua prosedur manual dan berkomputer 
pengesanan maklumat tanah. Sistem ini melibatkan proses kerja secara manual dan berkomputer. ${ }^{44}$

Pada tahun 2001 Kementerian Sumber Asli dan Alam Sekitar (NRE) telah melaksanakan kajian Sistem Pemodenan Pejabat Tanah atau singkatannya SPPT. Hasil dari kajian ini, pada 19 Januari 2005, Jemaah Menteri telah bersetuju Projek e-Tanah dilaksanakan secara perintis di Pentadbiran Tanah Negeri Pulau Pinang. Projek Perintis ini mula dibangunkan pada 12 Oktober 2005 dan siap pada 12 April 2008. Tapak Projek adalah Pejabat Tanah dan Galian (PTG) Pulau Pinang, Pejabat Tanah dan Daerah (PTD) Barat Daya, PTD Timur Laut, PTD Seberang Perai Utara, PTD Seberang Perai Tengah, PTG Seberang Perai Selatan. Sistem e-Tanah mengandungi sembilan (9) Modul Utama yang merangkumi 85 urusan. Modul Utama ialah modul Pembangunan tanah, Pelupusan tanah, Pendaftaran, Hak Milik Strata, Pengambilan Tanah, Kebenaran /kelulusan pindahmilik/cagaran, Hasil Tanah, Lelong dan Penguatkuasaan. ${ }^{45}$ Ia merupakan satu sistem yang dibangunkan berasaskan teknologi web yang bersepadu dan seragam untuk mempercepatkan dan mempertingkatkan sistem pencapaian perkhidmatan awam dalam pengurusan pentadbiran tanah di Semenanjung Malaysia. ${ }^{46}$ Kerajaan merasakan sistem e-tanah yang diperkenalkan boleh mengatasi masalah kelewatan dan kerenah birokrasi dalam pengurusan pentadbiran tanah di Pejabat Tanah dan Daerah (PTD). ${ }^{47}$ Prosedur yang digunakan dalam e-Tanah juga termasuk secara manual dan menggunakan komputer. Tandatangan digital ${ }^{48}$ oleh Pendaftar Hak milik juga diperkenalkan dalam sistem ini.

44 Seksyen Komputer Pentadbiran Tanah, Jabatan Ketua Pengarah Tanah dan Galian ( Persekutuan), Kementerian Sumber Asli dan Alam Sekitar http://www. kptg.gov.my/index.php?option=com_content\&view=article\&id=64\&Itemid=1 09\&lang=ms (akses pada 12 Mei 2011)

45 Raden Galuh, "Sistem e-Tanah", http://tanahmenanggung.blogspot.com/2009/ 08/sistem-e-tanah.html (akses pada 29 Julai 2011)

46 Malaysia, Perbahasan Dewan Rakyat, Bacaan Pertama, 29 Oktober 2008, 4 (Menteri Sumber Asli dan Alam Sekitar, Datuk Douglas Uggah Embas)

47 Hussain Said, "Sistem e-tanah Ke Seluruh Negara”, Berita Harian, 25 Mei, 2007.

48 Mengikut seksyen 5D Jadual Keenam Belas (KTN)(Tafsiran), tandatangan digital bermaksud transformasi pesanan yang menggunakan kriptosistem asimmetrik di mana orang yang mempunyai pesanan yang awal dan kunci awam penandatangan boleh menentukan secara tepat: (a) sama ada transformasi telah diwujudkan dengan menggunakan kunci persendirian yang sepadan dengan kunci awam penandatangan; dan (b) sama ada pesanan telah diubah sejak transformasi dibuat. 
Oleh kerana banyaknya kes frod yang dilakukan dalam sistem manual, integriti sistem Torrens dalam menjamin hak milik yang tidak boleh disangkal di bawah seksyen 340 KTN 1965 haruslah dikekalkan iaitu dalam sistem SPTB dan e-Tanah. Seperti contoh dalam sistem e- Tanah juga harus mengambil kira tahap keselamatan untuk mengurangkan dan mengesan frod, menggunakan tandatangan digital semasa pendaftaran hak milik dan meluluskan sesuatu permohonan yang sah dari segi undang-undang. Bagi mengatasi masalah frod, penambahbaikan sistem e-Tanah haruslah dipertingkatkan. Sistem e-Tanah merupakan satu pendekatan yang diambiloleh kerajaan bagi memantapkan dan memodenkan pentadbiran tanah serta mempertingkatkan sistem penyampaian perkhidmatan (service delivery system) dan juga boleh menaikkan imej Pejabat tanah. Oleh itu semua pihak haruslah memainkan peranan masing-masing dan berkerjasama bagi memastikan matlamat perlaksanaan sistem e-Tanah ini tercapai. ${ }^{49}$

Jenis-jenis frod di Australia adalah seperti berikut:

\section{Pemalsuan tanda-tangan}

Di Australia, menjadi kebiasaan bagi penjenayah dalam melakukan frod, mereka terdiri daripada orang yang dikenali oleh mangsa seperti ahli keluarga mangsa ${ }^{50}$, sahabat atau peguam. Keupayaan mereka

49 Haizan Yusoff, “ e-Tanah (e-Land) - An Integrated land Administration System" (kertas kerja yang dibentangkan di Seminar on Risk Reduction in Land Fraud, Shah Alam,Selangor, 22-23 Oktober, 2008).

50 Roushi Low, "Opportunities For Fraud In The Proposed Australian National Electronic Conveyancing System: Fact Or Fiction?," ELaw Journal:Murdoch University Electronic Journal Of Law 13, no.2 (2006), https://elaw.murdoch. edu.au/archives/issues/2006/2/_elaw_Fraud_article_puba_191006doc.pdf ( akses pada 13 Januari 2011). Dalam kes Young v Hoger [2002] QSC 013, Mr and Mrs Hoger were the joint tenants of their matrimonial home. Mrs Hoger and her daughter, Denice, sought to refinance an earlier loan by making an application to PJP Mortgage Management Pty Ltd (PJP), a mortgage broker, for an advance of $\$ 447,000$. This loan was to be secured by a registered mortgage over the matrimonial home. Mr hoger was unaware of this. When PJP found a client who was prepared to make the advance, it instructed its solicitor to prepare the mortgage documents. The solicitor sent the instrument of mortgage and a solicitor's certificate to Denice and Mrs Hoger for execution with an accompanying letter setting out requirements for execution. The mortgage instrument was returned by Denice to the solicitor, bearing the purported signatures of $\mathrm{Mr}$ and Mrshhoger and the signatures of a justice of the Peace, as witness to their 
untuk melakukan jenayah frod adalah kerana penipu boleh mengakses dokumen hak milik dan identiti dokumen tersebut. Apabila terdapat kehendak penyaksian,penipu menggunakan jalan pintas dengan memalsukan tandatangan saksi. Di Australia, National Electronic Conveyancing System (NECS) diperkenalkan ${ }^{51}$. Oleh itu manamana pihak yang mahu memasukkan instrumen untuk pendaftaran hendaklah memilih 'subscriber'52 untuk mewakili pihak tersebut dalam menggunakan sistem NECS untuk melengkapkan transaksi. 'Subscriber' hendaklah menentusahkan identiti klien. Apabila harta klien telah dikenalpasti seterusnya 'subscriber' akan melengkapkan borang pemberian kuasa klien untuk bertindak bagi pihak klien.

signatures. The trial judge found that Mr and Mrs Hogers' signatures on the mortgage were forged by Denice (her daughter). Dalam kes Sansom $v$ Westpac Banking Corporation (1996) Aust Torts Reports 81-383, in that case Mr and Mrs Sansom were the registered proprietors of their home in Port Macquqrie as well as joint holders of an overdraft account with Westpac banking Corporation. Mrs Sansom looked after their financial affairs and she signed most of the cheques drawn on their account. She ha also told the bank's officers that $\mathrm{Mr}$ Sansom was ill with cancer. On May 1985, the Port Macquqrie home was mortgage to the bank to secure an increase in the overdraft limit. Mr Sansom knew nothing about the mortgage. Mr Tongue, a senior officer of the bank gave Mrs Sansom the mortgage documents for the purpose of procuring Mr Sansom's signature. She forged Mr Sansom's signature on the mortgage and returned the document to the bank. Mr Tongue attested to Mr Sansom's signature to the mortgage document, falsely attesting that it signed in his presence. Later in 1987, the bank took mortgages over two more properties. Similar to the 1985 mortgage, Mr Monaghan, the banker's manager, allowed Mrs Sansom to take the mortgage documents home for Mr Sansom to sign. Again she forged $\mathrm{Mr}$ Sansom's signature on the mortgage documents and Mr Monaghan falsely attested that Mr Sansom had signed the mortgage documents in his presence. The 1987 mortgages were also registered. The bank did not get in contact with the husband before the mortgages were signed nor did the bank attempt to verify the truth as to Mr Sansom's illness. Handing over to Mrs Sansom's signature simply made it easier for Mrs Sansom to perpetrate the fraud.

51 The NEC is described as Australian's joint government and industry initiative to create an efficient and convenient way of completing proprerty based transactions and lodging land title dealings for registration. http://www.necs.gov.au/ Home/default.aspx (akses pada 1 Ogos 2011)

52 'Subscriber': these are corporations, partnerships, government agencies and individuals employing or contracting industry practitioners and others meeting the minimum requirements for representing clients in using the NECs to prepare and/or certify and sign instruments. Lihat juga National Electroni Conveyancing Office, 'Draf National Business Model For The Establishment Of A National Electronic Conveyancing System (National Electronic Conveyancing office, 2006), http://ww.,necs.gov.au/national-Business-Model/default.aspx.22 (akses pada 27 Julai 2011). 
Borang tersebut hendaklah ditandatangani dihadapan saksi. ${ }^{53}$ Dalam menurunkan tandatangan sesuatu dokumen, tandatangan digital digunakan bagi menggantikan tandatangan tulisan tangan.' Certifier ${ }^{54}$ dipertanggungjawabkan dalam menurunkan tandatangan bagi pihak klien dan mereka dikehendaki mendapatkan 'grade 2 Gatekeeper compliant Digital Signature Certificate (DSC) untuk tujuan menandatangani sesuatu instrumen..$^{55}$ Secara kesimpulannya ciri-ciri sistem NECS ialah akses kepada sistem elektronik hanya terhad kepada 'authorized user' ${ }^{56}$ kepada sistem tersebut, 'Subscriber' yang mewakili pihak klien hendaklah menandatangani borang pemberian kuasa di hadapan saksi, tandatangan digital digunakan menggantikan tandatangan tulisan tangan, 'Ceritfiers' telah diberi tanggungjawab untuk menandatangani dokumen secara tandatangan digital bagi pihak klien dan instrumen hendaklah disediakan secara elektronik dalam sistem NECS dan pemasukannya secara elektronik di pejabat pendaftaran tanah. ${ }^{57}$ Oleh itu dalam sistem NECS, setiap individu tidak lagi menandatangani instrumen

53 Roushi Low, "Opportunities For Fraud In The Proposed Australian National Electronic Conveyancing System: Fact Or Fiction?," ELaw Journal:Murdoch University Electronic Journal Of Law 13, no.2 (2006), https://elaw.murdoch. edu.au/archives/issues/2006/2/_elaw_Fraud_article_puba_191006doc.pdf( akses pada 13 Januari 2011).

54 'Certifier' these are industry practitioners employed by or contracted to a subscriber and authoriesd by that subscriber to prepare, certify and sign instruments. National Electroni Conveyancing Office, 'Draf National Business Model For The Establishment Of A National Electronic Conveyancing System( National electronic Conveyancing office, 2006) http://ww.,necs.gov.au/ national-Business-Model/default.aspx.22 (akses pada 27 Julai 2011).

55 National Electronic Conveyancing Office, 'Draf National Business Model For The Establishment Of A National Electronic Conveyancing System ( National electronic Conveyancing office, 2006) http://ww.,necs.gov.au/nationalBusiness-Model/default.aspx.22 (akses pada 27 Julai 2011), lihat juga Roushi Low, "Opportunities For Fraud In The Proposed Australian National Electronic Conveyancing System: Fact Or Fiction?," ELaw Journal: Murdoch University Electronic Journal Of Law 13, no.2 (2006), https://elaw.murdoch.edu.au/archives/issues/2006/2/_elaw_Fraud_article_puba_191006doc.pdf (akses pada 13 Januari 2011).

56 'User' means these are employees or contractors authorized by a subscriber to prepare but not certify or sign instruments.

57 Roushi Low, "Opportunities For Fraud In The Proposed Australian National Electronic Conveyancing System: Fact Or Fiction?" ELaw Journal:Murdoch University Electronic Journal Of Law 13, no.2 (2006): 239. https://elaw.murdoch.edu.au/archives/issues/2006/2/_elaw_Fraud_article_puba_191006doc. pdf ( akses pada 13 Januari 2011) 
tetapi Certifiers akan menandatangani dokumen secara tandatangan digital bagi pihak klien mereka. Oleh itu tidak mustahil frod akan berlaku dalam sistem NECS, apabila penipu berpeluang untuk memalsukan tandatangan mangsa dalam borang pemberian kuasa dan memalsukan tandatangan saksi atau mereka yang menjadi saksi kepada sesuatu tandatangan tidak mengikut prosedur penyaksian yang betul. ${ }^{58}$

\section{Penipuan oleh peguam}

Frod oleh peguam berlaku apabila peguam memalsukan tandatangan mangsa terutamanya dalam instrumen gadaian dan apabila peguam mengatur pinjaman tanpa pengetahuan atau autoriti mangsa. ${ }^{59}$ Kebiasaanya dalam kes frod oleh peguam berlaku kerana adalah mudah bagi mereka untuk mengakses dokumen seperti dalam kes surat ikatan hak milik mangsa. Di samping itu juga, peranan yang dimainkan oleh peguam dalam menyempurnakan proses pemindahhakkan dan kepercayaan yang diberikan oleh anak guam kepada peguam untuk menjalankan tugas dan tanggungjawab juga merupakan faktor penyumbang kepada berlakunya frod dalam kes ini. ${ }^{60}$ Untuk melakukan jenayah frod dalam sistem elektronik (NECS), boleh dikatakan peguam yang bertindak sebagai 'Ceritfiers' berpeluang untuk melakukan frod. ${ }^{61}$ Antara faktor yang

58 Ibid., 239.

59 Ibid., 233. Seperti contoh kes Registrar of Titles $v$ Franzon and Finance Corporation of Australia Ltd [1975] 132 CLR 611, Mr and Mrs Franzon were registered proprietor of an estate in fee simple as tenants in common in equal shares of land contained in five certificates of titles. Before $15^{\text {th }}$ July 1969 that land together with land owned by Mrs Franzon's mother, was mortgaged to secure moneys owing to A.G.C. ( General Finance ) Ltd (AGC). The solicitor for the Franzons 9Mr Hopkins) applied without their authority to Finance Corporation of Australia Ltd for a loan. When this loan was approved, the solicitor forged the Franzons signatures to a mortgage over their land to secure the loan. With the money advanced by Finance Corporation, Hopkins discharged the mortgage to AGC and misappropriated the moneys received.

60 Lihat Sharon Christensen, William Duncan, "Professional Liability and Property Transactions", The Federation Press, 2004, Lihat juga Roushi Low, "Opportunities For Fraud In The Proposed Australian National Electronic Conveyancing System: Fact Or Fiction?,” ELaw Journal:Murdoch University Electronic Journal Of Law 13, no.2 (2006)), https://elaw.murdoch.edu.au/ archives/issues/2006/2/_elaw_Fraud_article_puba_191006doc.pdf ( akses pada 13 Januari 2011)

61 Ibid., 240. 
menyebabkan peguam mempunyai peluang untuk melakukan frod dalam sistem elektronik ialah mereka berupaya untuk mengakses sistem tersebut serta berkebolehan untuk menandatangani instrumen secara digital bagi pihak klien dan tanda tangan digital tersebut tidak perlu kepada penyaksian. ${ }^{62}$

\section{3. 'Identity fraud'}

Frod identiti merujuk kepada 'mengambil maklumat seseorang secara tidak sah tanpa kebenarannya.' Kebiasaannya ia melibatkan seseorang yang membuat representasi palsu sama ada dia seperti orang lain atau orang rekaan/samaran dan menggunakan identiti palsu tersebut untuk melakukan perbuatan jenayah. ${ }^{63}$ Dalam kes frod dalam hak milik tanah, kebiasaannya identity fraud dilakukan oleh mereka yang dikenali oleh mangsa seperti ahli keluarga, sahabat yang dipercayai atau sanak sedara mangsa di mana mereka telah berjaya mengakses identiti dokumen mangsa. Jenayah frod ini juga berlaku dengan bantuan orang ketiga ${ }^{64}$ atau penipu itu sendiri yang

62 Roushi Low, "From Paper To Electronic : Exploring The Fraud Risk Stemming From The Use Of Technology To Automate The Australian Torrens System," Bond Law Review 21, no.2 (2009), http://epublications.bond.edu.au/blr/vol21/ iss2/7/ (akses pada 13 Januari 2011). This conclusion was also reached in Roushi Low, "Opportunities For Fraud In The Proposed Australian National Electronic Conveyancing System: Fact Or Fiction?," ELaw Journal: Murdoch University Electronic Journal Of Law 13, no.2 (2006), https://elaw.murdoch. edu.au/archives/issues/2006/2/_elaw_Fraud_article_puba_191006doc.pdf ( akses pada 13 Januari 2011)

63 Sharon Christensen,"Electronic land Dealings in Canada, New Zealand and the United Kingdom : Lessons for Australia," ELaw Journal:Murdoch University Electronic Journal Of Law 11, no. 4 (2004), http://eprints.qut.edu. au/10194/1/10194.pdf (akses pada 12 Januari 2011).

64 Seperti dalam kes Grgic v ANZ Banking Group Ltd (1994) 33 NSWLR 202, the father was the registered owner. His son had a copy of the certificate of title and other documents relating to the property. This was because of an earlier loan application was made to the Commonwealth Bank which was rejected and the documents were handed back to the son. In 1987, the son asked the father to enter into a guarantee for the son's new business but the father refused. The mother then colluded with a workmate to impersonate the father. The son, wife and the workmate went to the ANZ Bank and the son introduced the workmate as his father. The workmate was able to produce the certificate of title and other documents relating to the land. Officers of the bank prepared the mortgage document and the workmate signed (as the father). The officers witnessed the signature. Held: the fraud occurred because the bank officer accepted the introduction of the son that the workmate was his father. $\mathrm{He}$ did not ask for further identification. He also relied on the certificate of title and other documents relating to the land as proof that the workmate was the father. 
menyamar sebagai mangsa. Jenayah frod yang dilakukan adalah dengan menggunakan identiti dokumen palsu. Oleh itu identity fraud yang dilakukan sama ada pihak itu dikenali atau tidak oleh mangsa frod berlaku dalam keadaan apabila penipu dapat mengakses hak milik dokumen dan identiti dokumen yang lain ( sama ada asli atau palsu) dan menggunakan dokumen identiti tersebut untuk menyamar sebagai mangsa dan apabila peguam tidak berwaspada dalam menentusahkan identiti pihak yang hendak berurus niaga dengan tanah. ${ }^{65}$ Dalam sistem NECS, jenayah identity fraud akan terus berlaku jika 'Subscriber' tidak berwaspada dalam menentusahkan identiti pihak yang berurus niaga dengan mereka. ${ }^{66}$

Oleh itu melihat kepada perbincangan di atas mengenai jenis-jenis frod yang berlaku di Malaysia dan Australia, boleh disimpulkan bahawa di Malaysia kebanyakan kes-kes frod dalam urus niaga tanah melibatkan kes identity fraud iaitu sama ada identiti pemilik tanah dipalsukan atau memalsukan kad pengenalan dan juga memalsukan tandatangan dan pengakuan ${ }^{67}$. Sejajar dengan statistik yang dikeluarkan oleh Jabatan Jenayah Komersial, Polis Diraja Malaysia (PDRM) dari tahun 2005 hingga $2008^{68}$ mendapati daripada jumlah 272 kes sepanjang tempoh tersebut, frod yang dilakukan dengan menggunakan borang 14A iaitu sebanyak 87 (32\%) merupakan penyumbang tertinggi dalam frod urus niaga tanah, 49 (18\%) kes melibatkan pemalsuan surat kuasa wakil (PA), 37 (13.6\%) kes pengeluaran geran palsu, 9 (3.2\%) kes pemalsuan Perintah Mahkamah, 4 (1.5\%) kes bagi pemalsuan kad pengenalan, 4 (1.5\%) kes juga melibatkan penipuan jual beli (S\&P), kombinasi kes sebanyak $36(13.2 \%)$ kes dan lain-lain

65 Roushi Low, "Opportunities For Fraud In The Proposed Australian National Electronic Conveyancing System: Fact Or Fiction?," ELaw Journal:Murdoch University Electronic Journal Of Law 13, no.2 (2006), https://elaw.murdoch. edu.au/archives/issues/2006/2/_elaw_Fraud_article_puba_191006doc.pdf ( akses pada 13 Januari 2011)

66 Ibid., 241.

67 Kevin Kam and Shanmuga Kanesalingam, "MLC 2010: Recent Federal Court's Decision on section 340 of the National Land Code 1965: Tan Ying Hong v Tan Sian San \& Ors - Are Landowners and Banks Secured?" http:// www. malaysianbar.org (akses pada 31 Julai 2010).

68 Laporan daripada Jabatan Jenayah Komersial, Polis Diraja Malaysia, 2008. 
sebanyak 46 (16.9) kes $^{69}$. Oleh itu perlakuan atau aktiviti frod boleh berlaku dalam sistem manual maupun elektronik. Oleh itu, pelbagai modus operandi dengan menggunakan suratan palsu telah dilakukan oleh penjenayah dalam melakukan frod. Dengan modus operandi ini telah berjaya memperdaya pihak pejabat tanah sehingga menyebabkan penipuan pendaftaran urus niaga tanah berjaya dilaksanakan. Kebanyakkan kes hanya disedari oleh pemilik tanah asal setelah mereka hadir untuk pembayaran cukai tanah, tapak tanah mereka dibangunkan atau apabila mereka membuat semakan di pejabat tanah. Kejayaan jenayah frod juga berlaku dalam urus niaga tanah berpunca dari ruang-ruang kelemahan yang terdedah di pejabat tanah. ${ }^{70}$ Di Malaysia kebanyakan kes-kes frod dilakukan oleh para peguam, kerani dan runners, ahli keluarga, wakil korporat dan Pentadbir (seperti Pentadbir tanah, Pentadbir sistem). ${ }^{71}$

Manakala di Australia, jenayah penipuan dalam pemindahhakkan ${ }^{72}$ dan industri gadaian ${ }^{73}$ merupakan satu isu yang serius di seluruh

69 Lihat juga Muhammad Hafiz Shaari, "Fraud Dalam Urusan Pendaftaran Hakmilik: Kajian Di Pejabat Pendaftar Hakmilik Negeri Selangor, Shah Alam," (Tesis Ijazah Sarjana Muda, Universiti Teknologi Malaysia, 2009), 9. Lihat juga Mesyuarat Timbalan Ketua Pengarah Tanah Dan Galian Dengan Timbalan Pengarah Tanah Dan Galian Negeri, Mewajibkan Perserahan Urusniaga Dikemukakan Oleh Pemilik tanah Atau pihak-pihak Terlibat : Satu Langkah Ke arah Membasmi Penipuan Urusniaga, Bil. 3/2008, Hotel Felda Residence, Kuala Terengganu, 2008, hlm 3.

70 Suhaimi Othman, "Frod Dalam Urusan Tanah: Isu dan Penyelesaian," Jurnal INSTUN 1, Bil 2 (2008), http://www.instun.gov.my/index2.php?option=com docman\&task=doc_view\&gid=189\&Itemid=99999999 (akses pada 30 Julai 2011).

71 Nor Shahriza et al, "Identifying and Overcoming the Risk of Fraud in the Malaysian Electronic Land Administration System" ( kertas kerja dibentangkan di International Conference On Research and Innovation in Information System ICRIIS'11, Kuala Lumpur, Malaysia, 23-24 November 2011), 1-6.

72 Contoh penipuan dalam pemindahhakkan boleh dikategorikan dalam tiga jenis iaitu (1) penipuan melibatkan pemalsuan Dokumen Hak Milik, (2) pemalsuan melibatkan 'identity theft' dan penyamaran sebagai mangsa kepada penipuan,(3) penipuan melibatkan pemalsuan tandatangan ke atas gadaijanji dan Dokumen Hak Milik.

73 Juga dikenali sebagai 'mortgage fraud'. Definisi mortgage fraud oleh FBI Financial Crimes Section, Financial Institution Fraud Unit ( Mortgage Fraud: A guide For Investigation : 2003) adalah seperti berikut: "any material misstatement, misrepresentation or omission relied upon by an underwriter or lender to fund, purchase or insure a loan." By that definition, such fraud can clearly be committed by both lenders and applicants, even though the latter may not think their misrepresentations or omissions are significant enough to be a concern. Mortgage fraud is a broad term that can refer to many activities: (1) Inflating an appraisal in order to obtain a mortgage for more than a property is worth; (2) Claiming income or assets the borrower does not have; (3) Posing 
wilayah di Australia. Oleh itu, selagi pemindahhakkan melibatkan pendaftaran hak milik dan dokumen gadaian, sama ada ia melibatkan sistem pendaftaran secara manual atau elektronik, pemindahhakkan ini mudah dipengaruhi oleh frod. Kemajuan teknologi juga merupakan faktor penyumbang kepada berlakunya penipuan identiti (identity fraud). ${ }^{74}$ Kebanyakan kes-kes frod yang dilaporkan berlaku di Australia, kebanyakan penipu merupakan orang yang dikenali oleh mangsa seperti ahli keluarga mangsa, saudara-mara, kawan rapat dan peguamcara mangsa di mana mereka mampu dan berkesempatan untuk melakukan frod kerana kebiasaannya mereka merupakan orang yang dipercayai oleh mangsa dan mempunyai akses kepada dokumen yang diperlukan untuk melakukan frod..$^{75}$

\section{Cadangan Penyelesaian}

1. Pejabat tanah hendaklah berhati-hati apabila berurusan dengan urusan tanah terutama yang melibatkan hak milik tanah yang bernilai tinggi termasuk yang melibatkan tanah kerajaan Negeri dan Kerajaan Persekutuan. Penyemakan ketulenan dokumen yang dikemukakan berhubung dengan pindah milik tanah hendaklah diteliti dengan lebih terperinci seperti hanya

as a borrower on behalf of another who's actually making the purchase; and (4) Pretending to provide financial help to an economically stressed homeowner in order to skim off equity from the home, http://www.mortgageloan.com/ mortgage-fraud/about/ ( akses pada1 Mei 2012). Statistik juga menunjukkan bahawa $21 \%$ jenayah serius yang dilakukan dalam penipuan di Australia dan New Zealand melibatkan 'mortgage fraud'. Lihat Smith, G, Russell, "Serious Fraud in Australia and New Zealand", Australian Institute of Criminology and PricewaterhouseCoopers, Research and Public Policy Series N0.48, March 2003. Lihat juga Paul Watkins," Fraud in Conveyancing," ( kertas kerja yang dibentangkan di Australian Institute of Conveyancer 2007 National Conference, New South Wales, 23-25 Mac 2007), http://www.stewartau. com/multimedia/relatedmedia/Fraud_in_Conveyancing_AIC_National_ Conference Paper_2007.pdf (akses pada 13 Januari 2012).

74 Roushi Low, 'From Paper to Electronic: Exploring the Fraud Risk Stemming from the Use of Technology to Automate the Australian Torrens System' Bond Law Review 21(2), (2009), 107-132.

75 Celia Hammond, “The Abolition Of The Duplicate Certificate Of Title And Its Potential Effect On Fraudulent Claims Over Torrens Land," Australian Journal Of Property Law 8, (2000),115, Lihat juga Roushi Low, "Opportunities For Fraud In The Proposed Australian National Electronic Conveyancing System: Fact Or Fiction?," ELaw Journal:Murdoch University Electronic Journal Of Law 13, no.2 (2006), https://elaw.murdoch.edu.au/archives/issues/2006/2/_ elaw_Fraud_article_puba_191006doc.pdf ( akses pada 13 Januari 2011). 
dokumen asal diterima. Jika hanya salinan dokumen asal dikemukakan, akujanji atau akuan kebertanggungjawaban hendaklah dimasukkan serta butiran penyerah bagi memastikan kredibiliti dan integriti penyerahan. Kaveat Pendaftar juga perlu segera dimasukkan apabila ada aduan kes frod. Di samping itu juga anggota pentadbiran tanah diharapkan dapat mematuhi Garis panduan Keselamatan Sistem SPTB. ${ }^{76}$ Pengawalan sistem komputer perlu juga dipertingkatkan dan akses kepada dokumen berkaitan dalam SPTB perlu dihadkan mengikut keperluan penugasan kakitangan di pejabat tanah. ${ }^{77}$ Bagi mengatasi masalah frod, penambahbaikan sistem e-Tanah haruslah dipertingkatkan seperti memperkenalkan penggunaan cap jari dalam proses pindah milik tanah, integrasi dengan jabatan Pendaftaran Negara bagi menyemak dan mengesahkan kad pengenalan pemohon dan integrasi dengan e-Mahkamah agar pengesahan perintah mahkamah dapat dilaksanakan. ${ }^{78}$

2. Masalah yang timbul daripada sistem SPTB pada peringkat sistem ini mula berfungsi untuk kemasukan data dan pengeluaran geran baru. Oleh sebab terdapat frod penukaran pemilik tanah semasa kerja-kerja kemasukan data, satu unit audit dalaman perlu ditubuhkan bagi menyemak semula status pemilikan tanah yang mencurigakan. Jika terdapat unsur-unsur frod, maka siasatan dalaman perlu dilaksanakan bagi mengenal pasti kakitangan yang terlibat atau membuat laporan polis. ${ }^{79}$

76 Parlimen: Laman Blog Soal Jawab Parlimen, http://www.nre.gov.my/Parlimen/ archive/2008 (akses pada 12 Mac 2009).

77 Suhaimi Othman, "Frod Dalam Urusan Tanah: Isu dan Penyelesaian," Jurnal INSTUN 1, Bil 2 (2008), http://www.instun.gov.my/index2.php?option=com docman\&task=doc_view\&gid=189\&Itemid=99999999 (akses pada 30 Julai 2011).

78 Haizan Yusoff, "e-Tanah (e-Land) - An Integrated land Administration System" (kertas kerja yang dibentangkan di Seminar on Risk Reduction in Land Fraud, Shah Alam,Selangor, 22-23 Oktober, 2008).

79 Suhaimi Othman, "Frod Dalam Urusan Tanah: Isu dan Penyelesaian," Jurnal INSTUN 1, Bil 2 (2008), http://www.instun.gov.my/index2.php?option=com docman\&task=doc_view\&gid=189\&Itemid=99999999 (akses pada 30 Julai 2011). 
3. Adalah menjadi tanggungjawab pemunya berdaftar untuk mengambil langkah keselamatan supaya mereka tidak terjebak dalam kes frod dan pemalsuan. Cara yang paling selamat ialah dengan memasukkan kaveat persendirian ke atas tanah sendiri seperti diamalkan di negara lain. Di Australia, seksyen 74 (F) (1) telah memansuhkan seksyen 72 (1) the Real Property Act 1900 (NSW) yang membenarkan manamana pemunya berdaftar berdaftar untuk memasuki kaveat ke atas tanah mereka. Jika undang-undang tanah di Australia boleh meminda untuk membuat peruntukan sedemikian, oleh itu tiada sebab mengapa KTN tidak boleh meminda seksyen $323(1)^{80}$ selepas kita menerima pakai sistem Torrens dalam pendaftaran tanah seperti mana yang dipraktis di Australia. ${ }^{81}$

4. Batasan kepada pihak yang boleh menurunkan tandatangan secara elektronik. Di New Zealand hanya peguam cara yang sedang berkhidmat dan broker tanah yang berlesen sahaja yang boleh mengesahkan dan menurunkan tandatangan dalam e-Dealings. Situasi yang sama juga berlaku di Singapura di mana hanya peguam sahaja yang boleh menurunkan tandatangan elektronik dalam sistem kaveat, penarikan balik kaveat dan tempoh perlanjutan kaveat. Manakala di British Columbia hanya Juricert (peguam yang sah) atau notari sahaja yang boleh menurun tanda tangan instrumen secara elektronik. ${ }^{82}$ Di Malaysia, KTN telah menyediakan peruntukan khas dalam Jadual Keenam Belas kepada

80 Seksyen 323(1) KTN menyatakan bahawa: Orang-orang dan badan-badan yang atas permintaan siapa suatu kaveat sendirian boleh dimasukkan adalah: (a) mana-mana orang atau badan yang menuntut hak milik, atau apa-apa kepentingan yang boleh daftar... atau mana-mana hak kepada hak milik atau kepentingan sedemikian; (b) mana-mana orang atau badan yang menuntut yang dia berhak mendapat faedah di bawah mana-mana amanah yang menyentuh apa-apa tanah atau kepentingan sedemikian; dan (c) penjaga atau orang yang mewakili mana-mana remaja yang menuntut sebagai berhak seperti yang disebutkan dalam perenggan (b).

81 Cheryl Nicholson, Tan Ying Hong V. Tan Sian San \& Ors [2010]: The Aftermath, http://www.cljlaw.com/membersentry/articlesdisplayformat.asp?A_2010_6_ CLJ_xxix;torrens_system_and_land (akses pada 12 Januari 2011).

82 Rouhshi Low, Maintaining The Integrity Of The Torrens System In A Digital Environment : A Comparative Overview Of The Safeguards Used Within The Electronic Land Systems In Canada, New Zealand, United Kingdom And Singapore, http://www.lexixnexis.com/my/legal/search/journalsubmitForm.do (akses pada 11 Januari 2011). 
Pendaftar Hak Milik untuk mengesahkan pendaftaran hak milik dengan menggunakan tanda tangan digital tetapi tiada peruntukan khas yang telah digubal bagi pengamal undangundang untuk menurun tanda tangan secara elektronik bagi pihak klien. ${ }^{83}$ Satu kebaikannya ialah mudah untuk mengekalkan keselamatan dalam sistem yang tertutup ini (closed' system). Di samping itu juga dengan menghadkan kepada pihak peguam atau pendaftar dalam menurunkan tanda tangan, membolehkan peraturan dan tanggung jawab ke atas pihak berkenaan untuk menjaga keselamatan dokumen dan mencegah penyalahgunaan kuasa. ${ }^{84}$ United Nation Committee juga bersetuju tentang pemakaian tanda tangan digital. Mereka merumus seperti berikut: "electronic signatures can be used to authenticate deeds. When they are used there must be certainty of authorship, guarantees that there has been no change in transit, the signature cannot be repudiated and the data remained confidential" 85

5. Memperluaskan pelaksanaan sistem biometrik. Sistem biometrik bukan lagi merupakan satu sistem yang baru bagi industri teknologi yang mana ia telah diterima pakai di pelbagai negara dalam menuju era teknologi siber. Beberapa tahun dahulu, undang-undang telah menggunakan sistem biometrik sebagai satu pengenalan diri tetapi sekarang undang-undang telah berubah dari segi penggunaannya yang menekankan kepada penyelesaian masalah jenayah dan salah laku individu. Ini kerana sistem biometrik cap jari dapat membezakan seorang individu itu daripada individu lain. Sistem ini dapat digunakan untuk dua tujuan iaitu

83 Mohd Shukri Ismail, Electronic Land Administration System In Malaysia : The Need For New Enabling Provisions, http://www.kptg.gov.my/dmdocuments/ my_documents/pdf/paper_3.pdf (akses pada 5 Mac 2010).

84 Rouhshi Low, Maintaining The Integrity Of The Torrens System In A Digital Environment : A Comparative Overview Of The Safeguards Used Within The Electronic Land Systems In Canada, New Zealand, United Kingdom And Singapore, http://www.lexixnexis.com/my/legal/search/journalsubmitForm.do (akses pada 11 Januari 2011).

85 United Nations Economic Commission for Europe, Land administration in the UNECE Region: Development Trends and Main Principles, http://www. unece.org/eny/documents/2005/wpla/ECE-HBP-140-e.pdf (akses pada 30 Julai 2011). 
sebagai pengenalan dan pembuktian. ${ }^{86}$ Jabatan Tanah dan Galian (PTG) hendaklah memperluaskan pelaksanaan sistem biometrik di seluruh negara bagi membendung kegiatan atau sindiket frod urusan pindah hak milik tanah.

6. Mengesahkan identiti klien. Kurangnya pengesahan identiti seseorang yang hendak berurus niaga dengan tanah merupakan salah satu faktor penyumbang berlakunya frod identiti. Langkah yang boleh diambil untuk mencegah 'identity fraud' ialah identiti pihak yang hendak berurus niaga dengan tanah hendaklah disahkan atau dikenal pasti sebelum sesuatu transaksi itu disempurnakan. Oleh itu dicadangkan pihak peguam dan pihak yang menjadi saksi kepada pelaksanaan dokumen untuk memanggil semua pihak-pihak yang memasuki transaksi untuk berjumpa pada satu sesi di mana semua pihak akan bertemu daripada mereka bergantung kepada broker tanah atau estet agen. Langkah ini telah dijalankan di Queensland ${ }^{87}$ di mana pemegang gadai janji hendaklah mengambil langkah yang munasabah bagi memastikan mereka berurusan dengan pemilik sebenar tanah tersebut. Hak milik tidak boleh sangkal tidak akan diberikan kecuali pemegang gadai janji telah mengambil langkah yang munasabah untuk mengenal pasti pihak yang menurunkan tanda tangan sesuatu gadai janji.$^{8}$ Menurut Cocks dan Barry dalam penulisannya: "it is the identity of the party that is crucial, not the physical possession of the paper title. Fraud is perpetrated when someone impersonates another by stealing their identity. Having possession of the paper title is not enough in itself, it is simply indicative of identity". ${ }^{89}$

86 MohdHelmyAbdWahab,Biometrik-AlternatifKepadaKunciKeselamatanData, http://www.utusan.com.my/utusan/info.asp? $y=2005 \& \mathrm{dt}=0216 \& \mathrm{pub}=$ Utusan Malaysia\&sec=Megabait\&pg=me_01.htm (akses pada 1 Mac 2010).

87 Seksyen 11A Land Title Act 1994 (Qld)

88 Roushi Low, "Opportunities For Fraud In The Proposed Australian National Electronic Conveyancing System: Fact Or Fiction?," ELaw Journal:Murdoch University Electronic Journal Of Law 13, no. 2 (2006), https://elaw.murdoch. edu.au/archives/issues/2006/2/ elaw_Fraud_article_puba_191006doc.pdf (akses pada 13 Januari 2011)

89 Russell Cocks and John Barry, "Electronic Conveyancing: Challenges For The Torrens System" Australian Property Law Journal 8, no.3 (2001): 270- 276, lihat juga Roushi Low, "From Paper To Electronic: Exploring The Fraud Risk Stemming From The Use Of Technology To Automate The Australian Torrens System," Bond Law Review 21, no. 2 (2009), http://epublications.bond.edu.au/ blr/vol21/iss2/7/ (akses pada 13 Januari 2011). 
Di samping itu juga, keprihatinan yang lebih patut diambil kira dalam transaksi yang melibatkan klien yang tidak boleh berbahasa Inggeris dan Bahasa Malaysia untuk memastikan mereka mempunyai kesedaran tentang isi kandungan dokumen dan jenis transaksi yang mereka sempurnakan. Pelaksanaan dokumen hendaklah disaksikan hanya selepas pengesahan identiti semua pihak yang terlibat dalam transaksi tersebut. ${ }^{90}$ Pejabat Tanah juga bolehlah menghentikan amalan membenarkan pihak ketiga yang dapat menyediakan surat perwakilan kuasa kononnya surat tersebut daripada tuan punya tanah untuk mengambil surat ikatan hak milik pemilik tanah bagi pihaknya. ${ }^{91}$

7. Borang 14A merupakan instrumen yang digunakan dalam penukaran pemilikan tanah dan ia menunjukkan pemilik tanah bersetuju untuk memindah tanahnya kepada pihak lain. Borang 14A juga merupakan penyumbang tertinggi dalam frod urusan pertukaran hak milik tanah di mana penjenayah akan mengemukakan identiti palsu dan memalsukan tanda tangan pemilik asal pada borang tersebut. Isunya tidak ada satu mekanisme untuk mengesahkan bahawa tandatangan tersebut datangnya daripada pemilik tanah sebenar. Proses penyerahan dokumen di pejabat tanah juga tidak memerlukan kehadiran pemilik tanah secara persendirian dan ini menyebabkan pindah milik mudah dijalankan. Oleh itu dicadangkan perlu diwujudkan satu kad contoh tanda tangan pemilik tanah seperti amalan yang dipraktis di bank-bank. Bagi membolehkan sesuatu surat kuasa wakil (PA) diguna pakai, sekurangkurangnya hendaklah disaksikan oleh seorang Pesuruhjaya Sumpah. Bagi mengesahkan surat kuasa wakil (PA), ianya perlu didaftarkan di Mahkamah Tinggi dan kemudiannya didaftarkan di pejabat tanah. Setelah surat kuasa wakil (PA) didaftarkan, transaksi boleh dijalankan dan pihak pejabat tanah akan memproses segala transaksi melibatkan surat

90 Ainul Jariah, Hunud Abia Kadouf, Weaknesses In The Registration Of Land Dealings System In Malaysia: Suggestions For Improvements For Enhancing The System, http://www.cljlaw.com/membersentry/articlesdisplayformat.asp?A_ 20101 LNS 1; torrens system and land (akses pada 13 Januari 2011).

91 Cheryl Nicholson, Tan Ying Hong V. Tan Sian San \& Ors [2010]: The Aftermath, http://www.cljlaw.com/membersentry/articlesdisplayformat.asp?A_2010_6_ CLJ_xxix;torrens_system_and_land (akses pada 12 Januari 2011). 
kuasa wakil (PA) tersebut tanpa mempersoalkan kesahihan surat berkenaan. Oleh itu, prosedur untuk mendaftar Surat Kuasa Wakil (PA) ke pejabat tanah perlu dikaji semula supaya frod dan pemalsuan dapat dielakkan. Dalam kes ini ia berlaku apabila pejabat tanah menerima dokumen palsu sebagai tulen tanpa membuat apa-apa semakan pengesahan. ${ }^{92}$

8. Mempertingkatkan keselamatan dengan pemberitahuan/ notis elektronik. Teknologi elektronik yang mengurangkan kos polisi menghendaki pejabat pendaftaran tanah untuk melaporkan kepada pemilik tanah yang terlibat, mana-mana perubahan dalam status hak mereka sebelum atau selepas pendaftaran berkuat kuasa sebagai salah satu langkah keselamatan. Contohnya di Costa Rico, semenjak 2007, firma swasta (yang dikenali sebagai PPR) akan membuat pemeriksaan setiap hari ke atas pangkalan data daftar awam untuk mengenal pasti mana-mana transaksi yang telah didaftar dalam tempoh 24 jam yang akhir dan mana-mana transaksi yang tidak sahih secara automatik kaveat akan dimasukkan. Dalam 'English Land Registry' telah menjadi satu tradisi untuk memberitahu pemilik tanah tentang mana-mana perubahan kepada daftar apabila pejabat pendaftaran nampak ada kemungkinan berlakunya frod dan pengaruh tidak wajar. Oleh itu, pemberitahuan (notification) menjadi satu standard keselamatan dalam semua jenis pengkomputeran pejabat tanah. ${ }^{93}$

9. Untuk keselamatan surat ikatan hak milik, dicadangkan supaya dikeluarkan nombor pengenalan diri (client ID) kepada pemilik tanah berdaftar dan menghendaki nombor ini dimasukkan dalam transaksi elektronik sebelum transaksi boleh diterima untuk pemasukan oleh pejabat pendaftaran tanah. Cara ini menjadikan frod agak sukar dilakukan kerana penipu perlu mengetahui 'identifier' untuk pemasukan transaksi berjaya dilakukan. Oleh itu untuk memerangi frod

92 Suhaimi Othman, "Frod Dalam Urusan Tanah: Isu dan Penyelesaian" Jurnal INSTUN 1, Bil 2 (2008), http://www.instun.gov.my/index2.php?option=com docman\&task=doc_view\&gid=189\&Itemid=99999999 (akses pada 30 Julai 2011.)

93 Benito Arrunada, "Electronic Titling: Potential and Risks," New Zealand Law Journal, (2010), http://www.econ.upf.edu/docs/papers/downloads/1193.pdf (akses pada 11 Januari 2011). 
dalam keadaan ini, harus menjadi tanggung jawab pihak klien untuk menyimpan dengan selamat nombor pengenalan diri mereka. ${ }^{94}$

10. Beberapa perkara yang penting yang perlu dititik beratkan juga dalam sistem pendaftaran urus niaga tanah ialah seperti pemantauan, undang-undang, pendaftaran dan sistem yang akan diperkenalkan hendaklah boleh diterima pakai oleh komuniti, selamat dan dijamin kebolehterimaannya..$^{95} \mathrm{Di}$ samping itu juga, pihak yang berurusan diwajibkan hadir pada setiap peringkat transaksi, pendaftar tanah juga hendaklah mengambil langkah keselamatan apabila mendaftar pindah milik atau gadaian serta memperkenalkan skim jaminan untuk membayar ganti-rugi kepada mereka yang telah ditarik haknya ke atas tanah walaupun tanpa kesilapan yang dibuat oleh pemilik tanah tersebut. ${ }^{96}$ Beberapa pelan tindakan perlu diadakan untuk meminum kejadian frod yang telah menjadi satu masalah global di seluruh negara seperti melatih penguatkuasa undang-undang untuk memahami tentang amalan kepada skim frod tanah, bagaimana melakukan penyiasatan dan mensabitkan kesalahan dan membangun satu sistem kepada Pendaftar Hak milik Tanah untuk mengesan frod dalam beberapa jenis transaksi yang menjadi kebiasaannya kejadian frod dilakukan. ${ }^{97}$

11. Seksyen 340(2) (a) KTN hanya memperuntukkan keadaan dimana hak milik yang diperolehi oleh seseorang akan boleh disangkal jika seseorang atau ejennya tahu mengenai

94 Roushi Low, "From Paper To Electronic : Exploring The Fraud Risk Stemming From The Use Of Technology To Automate The Australian Torrens System," Bond Law Review 21, no. 2 (2009), http://epublications.bond.edu.au/blr/vol21/ iss $2 / 7 /$ (akses pada 13 Januari 2011).

95 Trevor Mills," Can There Be A Model Title Registration System," (kertas kerja yang dibentangkan di Pacific Rim Real Estate Society (PRRES) Conference 2000, Sydney, Australia, 23-27 Januari, 2000).

96 Teo Keang Sood, "Deferred Indefeasibility Reinstated in the Malaysian Torrens System: The End of an Unfortunate Saga," Singapore Journal of Legal Studies, (2010): 26.

97 J David Stanfield, Jeff Underwood, Kirthimala Gunaskera, "Land Registration and Land Fraud in the United States," ( kertas kerja yang dibentangkan di Seminar On Risk Reduction in Land Fraud, Shah Alam, Selangor, 22-23 Oktober,2008). 
kewujudan frod dan merupakan pihak atau privy kepada frod. Dalam KTN sendiri tidak diterangkan dengan jelas tentang perlakuan yang bagaimana boleh dikatakan sebagai frod menurut maksud KTN. Oleh itu penulis berpendapat definisi frod haruslah diperjelaskan dalam KTN walaupun menurut Visu Sinnadurai dan Rouhshi, ia terpulang kepada tafsiran kehakiman tentang definisi 'fraud' dalam bidang kuasa Torrens bagi menentukan apa yang terjumlah sebagai frod. ${ }^{98}$ Penulis tertarik dengan definisi yang diberikan dalam peruntukan undang-undang di Nova Scotia, Kanada, ${ }^{99}$ mengenai perlakuan yang bagaimanakah yang dikatakan sebagai frod, iaitu seseorang itu dikatakan mendapat kepentingan melalui frod, jika seseorang pada masa transaksi:

(a) mempunyai pengetahuan sebenar tentang kepentingan yang tidak didaftarkan atau direkodkan;

(b) mempunyai pengetahuan sebenar bahawa transaksi itu tidak diberi kuasa oleh pemilik kepentingan yang tidak didaftarkan atau direkodkan;

(c) mengetahui atau sepatutnya telah mengetahui bahawa transaksi itu akan menjejaskan kepentingan yang tidak didaftarkan atau direkodkan.

98 Visu Sinnadurai, Jual Beli Harta Tanah Di Malaysia (Kuala Lumpur: Dewan Bahasa dan Pustaka, 1996), 319. Pandangan ini juga dipersetujui oleh Rouhshi di mana tiada penerangan atau definisi dalam perundangan apa yang dimaksudkan sebagai frod. Oleh itu ia terpulang kepada interpretasi kehakiman untuk menentukan apa yang terjumlah sebagai penipun. Lihat Rouhshi Low, "The Use Of Technology To Automate The Registration Process Within The Torrens System And Its Impact On Fraud: An Analysis”, (PhD diss., Queensland University of Technology, 2008), 32.

99 Nova Scotia Land Registration Act, Seksyen 4 (4): A person obtains an interest through fraud if that person, at the time of the transaction: (a) had actual knowledge of an interest that was not registered or recorded; (b) had actual knowledge that the transaction was not authorized by the owner of the interest that was not registered or recorded; and (c) knew or ought to have known that the transaction would prejudice the interest that was not registered or recorded. Dengan erti kata lain, hanya pengetahuan tentang kewujudan sesuatu kepentingan akan terjumlah sebagai frod terhadap pemegang kepentingan yang terdahulu, jika pemilik baru tahu atau mengambil maklum bahawa pendaftaran yang akan dilakukan akan menjejaskan kepentingan yang sedia ada pada tanah tersebut. Lihat Greg Taylor, "The Torrens System in Nova Scotia and New Brunswick," Australian Property Law Journal 16 (2009) : 307-308. 
Oleh itu diharap definisi frod dapat dimasukkan dalam KTN bagi memperjelaskan lagi apa yang dikatakan terjumlah sebagai frod.

12. Pegawai dan kakitangan di pejabat tanah perlu didedahkan kepada jenis atau bentuk frod dan pemalsuan yang telah berlaku dalam pentadbiran tanah agar mereka lebih berhatihati dan berwaspada kepada kemungkinan-kemungkinan berlakunya frod dan pemalsuan lebih-lebih lagi frod alaf baru dalam sistem elektronik, ${ }^{100}$ Perkara ini juga ditekankan oleh mantan Ketua Hakim Negara, Tun Zaki Azmi semasa beliau menyampaikan penghakiman kes Tan Ying Hong $v$ Tan Siang San \& Ors ${ }^{101}$ berharap agar Pihak Berkuasa Tanah mengambil langkah yang lebih cermat dan berhati-hati apabila melakukan pendaftaran urus niaga tanah. Oleh itu pihak pentadbir tanah dan pendaftar yang bertanggungjawab dalam mendaftar sebarang urus niaga hendaklah memastikan tugas yang dipikul dapat dilaksanaan dengan baik bagi melindungi pihak-pihak berkepentingan yang tidak bersalah daripada menjadi mangsa penipuan dan pemalsuan oleh mereka yang tidak bertanggungjawab. Di samping itu juga program latihan juga perlu diadakan bagi menerangkan jenis atau bentuk frod di mana peminjam dan pemilik tanah kebiasaannya menjadi sasaran penipu dalam melakukan kegiatan mereka.

\section{Bibliografi}

Ain, Abd. Halim. "Penipuan dalam Urusan Tanah-Kelemahan, Amalan Terbaik Dan Cadangan Bagi Mengatasinya." Jurnal Instun 1, Bil.2 (2008), www.instun.gov.my/index2. php?option $=$ com_docman\&task $=$ doc... $\quad$ (akses pada 6 Februari 2010).

Arrunada, Benito. "Electronic Titling: Potential and Risks." New Zealand Law Journal, (2010), http://www.econ.upf.edu/docs/ papers/downloads/1193.pdf (akses pada 11 Januari 2011).

100 Abd. Halim Ain, "Frod dalam Urusan Tanah-Kelemahan, Amalan Terbaik Dan Cadangan Bagi Mengatasinya," Jurnal Instun 1, Bil.2 (2008), www.instun. gov.my/index2.php?option=com_docman\&task=doc... (6 February 2010). $101[2010] 2$ MLJ 1. 
Christensen, Sharon. "Electronic land Dealings in Canada, New Zealand and the United Kingdom: Lessons for Australia." ELaw Journal: Murdoch University Electronic Journal Of Law 11, no. 4 (2004), http://eprints.qut.edu. au/10194/1/10194.pdf (akses pada 12 Januari 2011.

Christensen, Sharon. Duncan, William. "Professional Liability and Property Transactions.” The Federation Press, 2004.

Cocks, Russell. Barry, John,“ Electronic Conveyancing: Challenges For The Torrens System." Australian Property Law Journal 8, no.3 (2001): 270- 276.

Dass, K.The Torrens System In Malaya. Singapura: Malayan Law Journal Limited.1963.

Hammond, Celia. "TheAbolition OfThe Duplicate Certificate OfTitle And Its Potential Effect On Fraudulent Claims Over Torrens Land." Australian Journal of Property Law 8, (2000): 115.

Ismail, Shukri. Electronic Land Administration System In Malaysia: The Need For New Enabling Provisions. http://www.kptg.gov. my/dmdocuments/my_documents/pdf/paper_3.pdf(akses pada 5 Mac 2010).

Kam, Kevin. Kanesalingam, Shanmuga. MLC 2010: Recent Federal Court's Decision on section 340 of the National Land Code 1965: Tan Ying Hong v Tan Sian San \& Ors -- Are Landowners and Banks Secured?. http:// www.malaysianbar. org (akses pada 31 Julai 2010).

Keang Sood, Teo. "Deferred Indefeasibility Reinstated in the Malaysian Torrens System: The End of an Unfortunate Saga." Singapore Journal of Legal Studies, (2010): 26.

Koshy, Shaila. "Your Land Can Land In The Wrong Hands." The Star, August 8, 2010.

Low, Rouhshi. "The Use Of Technology To Automate The Registration Process Within The Torrens System And Its Impact On Fraud: An Analysis." PhD diss., Queensland University of Technology, 2008. 
Low, Rouhshi. Maintaining The Integrity Of The Torrens System In A Digital Environment: A Comparative Overview Of The Safeguards Used Within The Electronic Land Systems In Canada, New Zealand, United Kingdom And Singapore. http:// www.lexixnexis.com/my/legal/search/journalsubmitForm.do (akses pada 11 Januari 2011).

Low, Roushi. "From Paper To Electronic: Exploring The Fraud Risk Stemming from the Use of Technology to Automate the Australian Torrens System." Bond Law Review 21, no.2 (2009)), http://epublications.bond.edu.au/blr/vol21/iss2/7/ (akses pada 13 Januari 2011).

Low, Roushi. "Opportunities For Fraud In The Proposed Australian National Electronic Conveyancing System: Fact Or Fiction?." ELaw Journal:Murdoch University Electronic Journal Of Law 13, no. 2 (2006), .https://elaw.murdoch.edu.au/archives/ issues/2006/2/_elaw_Fraud_article_puba_191006doc.pdf (akses pada 13 Januari 2011).

Maidin, Ainul Jaria. "Historical Development of Land Law in Malaysia." Dalam Principles Of Malaysian Land Law, disusun oleh Ainul Jariah, Sharifah Zubaidah Syed Abdul Kader, Bashiran Begum, et.al,45, Kuala Lumpur :Lexis Nexis, Malayan Law Journal, 2008.

Maidin, Ainul Jariah. Kadouf, Hunud Abia. Weaknesses In The Registration Of Land Dealings System In Malaysia: Suggestions For Improvements For Enhancing The System. http://www.cljlaw.com/membersentry/articlesdisplayformat. asp?A_2010_1_LNS_1;torrens_system_and_land ( akses pada $1 \overline{3}$ Januari 2011 ).

Mills, Trevor. "Can There Be A Model Title Registration System." Kertas kerja yang dibentangkan di Pacific Rim Real Estate Society (PRRES) Conference 2000, Sydney, Australia, 23-27 Januari, 2000.

Idris, S.M. Gubal Kod Tanah Atasi Frod. http://pasbukitbendera. com/index.php?option $=$ com_content\&task $=$ view\&id $=883 \&$ i temid $=44$ (akses pada 26 Julai 2011). 
Nicholson, Cheryl. Tan Ying Hong V. Tan Sian San \& Ors [2010]: The Aftermath. http://www.cljlaw.com/membersentry/articles displayformat.asp?A 2010 6 CLJ xxix;torrens system and land (akses pada 12 Januari 2011).

Othman, Suhaimi. "Frod Dalam Urusan Tanah: Isu dan Penyelesaian." Jurnal INSTUN 1, Bil 2 (2008), http://www. instun.gov.my/index2.php?option $=\mathrm{com}$ docman\&task $=\mathrm{doc}$ view\&gid=189\&Itemid=99999999 (akses pada 30 Julai 2011).

Said, Hussain. "Sistem e-tanah Ke Seluruh Negara", Berita Harian, 25 May, 2007.

Sathiaseelan, Joshua Kevin. Prinsip-prinsip Penting Perundangan Tanah di Malaysia. Selangor: Lexis Nexis Malayan Law Journal, 2006.

Shaari, Hafiz. "Fraud dalam Urusan Pendaftaran hakmilik: Kajian Di Pejabat Pendaftar Hak, milik Negeri Selangor, Shah Alam." Tesis Sarjana Muda, Universiti Teknologi Malaysia, 2009.

Shahriza, Nor. et al. "Identifying and Overcoming the Risk of Fraud in the Malaysian Electronic Land Administration System." Kertas kerja dibentangkan di International Conference On Research and Innovation in Information System ICRIIS'11, Kuala Lumpur, Malaysia, 23-24 November 2011.

Sihombing, Judith. National Land Code, A Commentary. Kuala Lumpur: Malaysian Law Journal, 1992.

Sinnadurai, Visu. Jual Beli Harta Tanah Di Malaysia. Kuala Lumpur: Dewan Bahasa dan Pustaka, 1996.

Stanfield J, David. Underwood, Jeff. Gunaskera, Kirthimala. "Land Registration and Land Fraud in the United States", kertas kerja yang dibentangkan di Seminar On Risk Reduction in Land Fraud, Shah Alam, Selangor, 22-23 Oktober,2008.

Taylor, Greg. "The Torrens System in Nova Scotia and New Brunswick." Australian Property Law Journal 16 (2009): 307-308. 
Torrens R, Robert. The South Australian System By Registration of Title. Adelaide: Register and Observer General Printing Offices, 1859

Watkins, Paul. “ Fraud In Convenyancing," kertaskerja yang dibentangkan di Australian Institute of Conveyancer2007 National Conference, New South Wales, 23-25 Mac 2007, http://www.stewartau.com/multimedia/relatedmedia/Fraud in_Conveyancing_AIC_National_Conference_Paper_2007. pdf (akses pada 13 Januari 2012)

Yusoff, Haizan." e-Tanah (e-Land) - An Integrated land Administration System," kertas kerja yang dibentangkan di Seminar on Risk Reduction in Land Fraud, Shah Alam, Selangor, 22-23 Oktober, 2008. 